\title{
DYNAMICS OF THE COLD WAR CONCEPT'S FIGURATIVE COMPONENT IN THE US POLITICAL DISCOURSE
}

\author{
Nikita A. Kovalev \\ MGIMO University (Moscow, Russia) \\ nikitakovalyov@yandex.ru
}

\begin{abstract}
The article presents the results of a study aimed at analyzing the dynamics of the development of the COLD WAR concept's figurative component in political discourse based on the material of the American media. The research conducted using the methods of discursive, conceptualdefinitional and comparative analysis has shown that the COLD WAR concept is a complex multi-component concept-scenario (or dynamic frame) that evolved during the second half of the $20^{\text {th }}$ century. The figurative component of the concept manifests itself in its metaphorization and develops as the concept penetrates into the American mass consciousness. Throughout its history the COLD WAR concept has been both the source domain and the target domain of metaphorization with numerous models of metaphorical reinterpretation. Moreover, the author states that demetaphorization of the concept has also played a big part in the development of its figurative component. The article opens up a perspective for the study of the conceptual field of the "cold war" in different linguocultures, which is very important considering the changing international situation and the emergence of such concepts as COLD WAR 2, COLD WAR 2.0, etc.
\end{abstract}

Keywords: cognitive linguistics, political discourse, concept, framework, conceptual metaphor, cold war.

\section{INTRODUCTION}

The cold war is the longest conflict in the history of the twentieth century which covered many countries on almost all continents [Gaddis, 1998; Leffler \& Westad, 2010]. The COLD WAR concept, which is so important for the consciousness of many nations, was born a little earlier than the beginning of the global confrontation itself with the help of the outstanding English writer George Orwell [Orwell, 1945] and has undergone continuous changes throughout its history. It should be noted that the concept did not lose its relevance at the end of the $20^{\text {th }}$ century after the end of the cold war, but it also continued to function in new realities with the appearance of such new concepts as SECOND COLD WAR, COLD WAR 2, COLD WAR 2.0.

The topicality of this paper is that language means of representation of concepts require constant study especially in case of complex and multi-component concepts such as the COLD WAR concept. The scientific novelty of the suggested research is the application of framework semantics methods to the study of complex concepts in their evolution. It is the first time that the analysis of the development of the figurative component of the COLD WAR concept within the framework of American political discourse has ever been conducted.

The aim of this paper is to study metaphorical models of the COLD WAR concept using the empirical material of American press published from 1947 to 1991, and to analyze diachronic changes in the figurative component of this concept represented by these models. To achieve this goal, it is important to solve the following problems and task:

- identification of metaphorical models, in which the COLD WAR concept acts as a source domain and a target domain, within the chronological framework of the cold war;

- detailed analysis of the aforementioned models from the viewpoint of the structure of the COLD WAR dynamic framework; 
- tracing changes in the figurative component of the concept.

\section{MATERIAL AND METHODS}

The methodological basis of the study, which helps to achieve the reliability and validity of the conclusions in the paper, is made up of the works of scientists in the field of cognitive linguistics [Babushkin, 1996; Demyankov, 1994; Karasik, 2002; Kubrjakova, 1996; Lakoff \& Johnson, 2003], discourse theory [Halliday, 1978; Dijk, 1995], political linguistics and the research of political discourse [Chudinov, 2011; Sheigal, 2000], and cold war historiography [Cowley, 2006; Crockatt, 1994; Dockrill \& Hopkins, 2006; Egorova, 2003; Gaddis, 2005; Kendall, 2017]. Ideas presented in these works helped to identify the type and complexity of the concept under consideration, its functioning in political discourse, as well as to consider the time frame and stages of the research. The research uses methods and techniques including conceptual modeling; definition, interpretative, component, contextual, etymological analysis; conceptual analysis methodology, observation, comparison, discursive analysis, and elements of content analysis.

In accordance with the objectives of the study, we have developed a methodology for the study of complex concepts in diachrony, which includes

- determining the time interval of the study and its chronological stages,

- building a basic framework model based on the analysis of materials from lexicographic sources,

- $\quad$ choosing a lexical unit that makes up the name of the framework, followed by the selection of the notional, figurative, and value components of the concept;

- $\quad$ modeling the concept at the selected stages;

- analysis of changes in the structure and content of the concept under consideration.

Identification of the figurative component of the concept is carried out through the analysis of models of metaphorical transfer of the concept, as well as cases of its demetaphorization at the chosen stages of the research. The concept acts as the source domain and the target domain of metaphorical transfer, thereby not only accentuating the cognitive features presented in the notional component, but also generating new ones. These cognitive features complement the existing concept scheme in the form of framework components.

The research is based on the empirical materials of the US quality press published from 1947 to 1991 (Adirondack Daily Enterprise, Brooklyn Eagle, Buffalo Courier Express, Cortland Standard, Millbrook Round Table, News-Journal, Press-Republican, Utica Observer Dispatch, Watertown Daily Times, The Daily Record, The Hilton Record, Hilton, The Journal, The Leader-Herald, The Morning Herald, The Otsego Farmer, The Portville Star, The Stylus, The Times Record, The Villager).

\section{RESULTS AND DISCUSSION}

From the linguistic point of view, the COLD WAR concept is a complex multicomponent structure that is subject to constant changes under the influence of extralinguistic factors [Babushkin, 1996], i.e. it is a dynamic framework (or a concept-scenario) [Minsky, 1975]. Analysis of the historiographical literature allows us to identify five stages of the cold war, within which the study was conducted, namely the beginning of the cold war (1947-1953), the period of escalation (1953-1962), the achievement of strategic parity (19621969), the defusing of international tensions (1969-1979), a new round of confrontation and the end of the cold war (1979-1991) [Cowley, 2006; Egorova, 2003]. After studying a lot of lexicographic sources we managed to model the basic scheme of the COLD WAR conceptscenario [Kovalev, 2017]. 


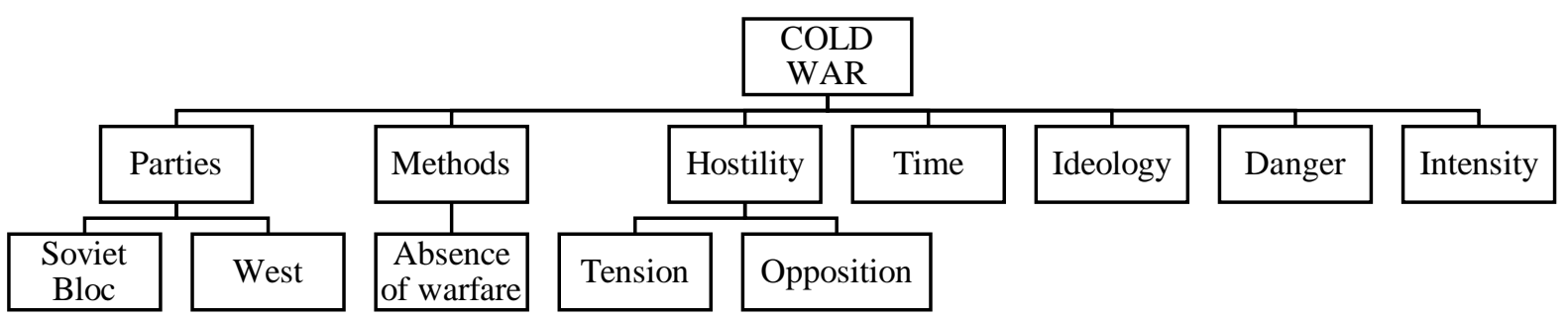

Diagram 1. The COLD WAR framework basic model

Like all complex concepts, the COLD WAR concept has value, notional, and figurative components [Karasik, 2002]. The value component of the concept is determined by the role that the concept plays in the language consciousness, which is reflected in a large number of appeals to the concept. The notional component of the COLD WAR concept is determined primarily by the appearance of new participants in the confrontation, methods of conflict management, and the accentuation of the ideological component from the point of view of values and religion. The figurative component of concepts includes "visual, tactile, auditory, and other characteristics of objects, phenomena, and events reflected in people's memory" (translated by the author) [Op. cit., p. 5.]. Metaphorization, which, in its broad sense, includes not only examples of metaphors, but also comparison, metonymic transfer, etc., is also responsible for the figurative component of concepts. The analysis of press materials published during the cold war revealed that the COLD WAR concept was actively metaphorized, and acted as both the source domain and the target domain of metaphorical transfer.

\subsection{The COLD WAR concept's figurative component (1947-1953)}

Analysis of the press published during the first period of the cold war showed that the concept of COLD WAR was actively metaphorized, and acted both as a source domain and a target sphere of metaphorical transfer. Some linguists also define it as "left motivation" and "right motivation" of metaphorical transfer [Tolstaja, 2004].

\subsubsection{COLD WAR as the source domain of metaphorical transfer}

Temperature metaphor. The phrase cold war itself is a metaphor, thus, during the entire existence of the concept the lexeme cold has often been metaphorically reinterpreted. It tends to have a negative connotation if carrying extreme values (both cold and hot), and a gradual increase in temperature has a positive meaning, as shown by the choice of lexical units to characterize certain phenomena of reality.

Cold War Keeps Chill Off Industry (1950).

Military Men Will Analyze Hot-Cold War (1952).

Western Europe looked toward the new year and the East today with a general conviction that the Russians will hesitate to march in 1953 but will keep the cold war hot (1952).

Cold War Getting Warmer(1952).

Military metaphor. A large role in the functioning of the cold war concept is played by military metaphor, which is structurally displayed in the Warfare slot of the Methods subframe. Although military vocabulary is more characteristic of the representation of the WAR concept, it was often used to characterize the conduct of non-military confrontation, especially at the early stages of the cold war.

As the U. S. envoy to a government under hot fire from Moscow (1949).

Senator Sees U.S. Losing “Cold War” Utica Observer Dispatch (1949).

Russia Has Lost a Battle in the Cold War - Not the Entire War (1949). 
the Soviets may launch a new peace offensive in the new year to try to disarm the West, quiet the continued war fears of western European leaders and thereby weaken the newly found western unity (1949).

A Russian effort to effect a truce in the cold war, however, is also regarded as quite possible. In the American view it would be a tactical move (1949).

Game metaphor. Any confrontation, and especially the cold war, is a competition, as evidenced by the fact that from the very beginning of the global conflict in the late 1940s, the cold war was presented as a game (both gambling and sports). This metaphorical model has proved to be highly productive.

If the cold war is anything like going to baseball games has been the past few days, we are in favor of calling the whole thing off (1949).

COLD WAR SCORE IS UNDETERMINED ... a recurring cat-and-mouse game in Europe and a Chinese puzzle in Asia and in western Europe - we enjoy a stalemate, at worst; at best, we're head (1950).

Religious metaphor. Moral legitimization of the confrontation between the West and the USSR was boosted by the accentuation of the CHRISTIANITY-ATHEISM opposition, structurally displayed in the Religion slot of the Ideology subframe, presented in the basic model of the concept. The actions of the US containment of the Soviet Union was described as an ideological "crusade" against communism. The trip to Europe and the holding of a conference in Moscow by Trygve Halvdan Lie, the first UN Secretary-General, was called a "pilgrimage of peace". It should be noted that the lexical-semantic field (LSF) of religion was represented quite extensively at the first stage of the cold war.

Lie's Moscow press conference came at the end of his "pilgrimage of peace" which began with conferences with President Truman and Secretary of State Dean ... (1950). Therefore, the question arises as to how this ideological crusade is to be met ... It is a proposal for moral and spiritual cooperation of God-fearing free nations (1951).

Zoomorphic metaphor. The cold war is reinterpreted through comparison with a wild beast. Many researchers, e.g. S.M. Tolstaja, argue that "animal" metaphors are often associated with negative, pejorative assessments of objects in the extra-linguistic reality [Tolstaja, 2004].

The fourth estate here in the nation's capital is feeling the harsh breath of the cold war (1950).

\subsubsection{COLD WAR as the target domain of metaphorical transfer}

Political metaphor. Starting from the first years of its existence, the COLD WAR concept began to be transferred to such an area as domestic politics, in contrast to the sphere of global politics, within which the concept initially originated. For instance, the election race between Harry Truman and New York Governor Thomas Edmund Dewey was compared to the cold war.

Dewey Pushing a Cold War against Truman (1948).

The above mentioned metaphorical models are reflected in the structure of the COLD WAR concept at the first stage of its existence. A metaphorical model based on a reinterpretation of the temperature vocabulary corresponds to the Temperature slot absent in the basic concept model. New other components include the Religion slot of the Ideology subframe (see Diag. 2), and the Game slot of the Spheres subframe (see Diag. 3). The military metaphor structurally fits into the Warfare slot of the Methods subframe, the zoomorphic metaphor illustrates hostility (the Hostility slot), and the political metaphor corresponds to the Politics slot of the Spheres subframe. Bold text in the diagrams highlights the new components in the concept structure. 


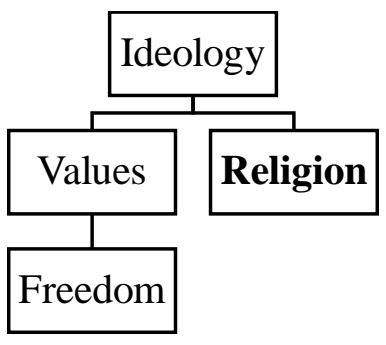

Diagram 2

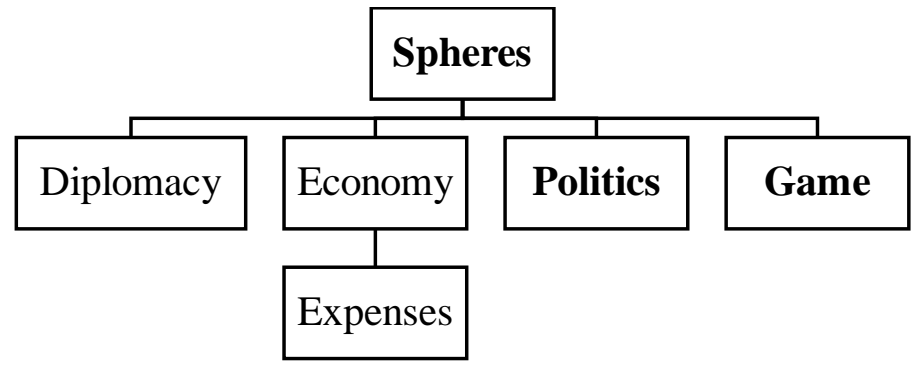

Diagram 3

\subsection{The COLD WAR concept's figurative component (1953-1962)}

\subsubsection{COLD WAR as the source domain of metaphorical transfer}

Temperature metaphor and climate metaphor. Like in the first stage of the cold war, a large amount of vocabulary nominating temperature was used in the US political discourse to describe the state of affairs in the world politics, metaphorically describing the nature of relationships between the competing superpowers. Closely related to the temperature sphere, the area of weather and climate is the source of metaphorical reinterpretation of the COLD WAR concept, with the THAW target domain playing an important role as a symbol of improving relationships.

If me cold war with international Communism turns hot, America's most advanced base would be a cluster of runways and huts, huddled on the frozen, lonesome reaches of the Yukon River (1955).

WINSTON CITES DANGERS ABOUT COLD WAR THAW. Sir Winston Churchill, 84, feeble in body but as assertive as ever, says the signs of a thaw in the cold war must not mislead the West into hasty disarmament agreements with the Soviet Union (1958).

The lowering clouds on the international horizon are worrying both Presidential campaign camps. The Republican leaders here and the Democratic strategists in Hyannis Port, Mass., are anxiously watching the cold war barometer (1960).

Military metaphor. The second phase of the cold war generated a large amount of military vocabulary and military metaphors regarding the COLD WAR concept. It proves relevance of comparison of the cold war with a conventional confrontation.

Lippmann Sees Hope in Armistice in Cold War (1951).

"The cold war has taken a new offensive pattern. Communist Russia is using trade and aid as weapons in an undramatic but effective program to erode the Free World and extend the borders of the Communist Empire" (1958).

Sparkman, the 1952 Democratic vice presidential nominee, said he and Stevenson felt that the Eisenhower administration had not been active enough in countering Moscow's "peace offensive" (1953). 
Game metaphor. Actions of the opposing sides continued to be compared to gambling. At the second stage of the cold war the number of appeals to the sphere of gambling rose significantly.

Next Cold War Round (1955).

We can hope that Khrushchev is bluffing, but we cannot afford to gamble on it (1959).

Religious metaphor. The buildup of nuclear weapons raised serious fears and concerns and was described as biblical Armageddon. In its broad sense, the sphere of religion remained essential for uniting US citizens to confront and oppose communist ideas.

The decisive cold war battle over the Middle East seems about to be joined. For western civilization, this is a moment for prayerful resolve. The democratic world faces a toeto-toe struggle with Communism ... (1957).

The Cold War Armageddon (1961).

Morbial metaphor. Despite the extremely tense relations on the world arena, there still was an understanding that it was necessary to put an end to the confrontation, despite the fact that it was difficult. The cold war was compared to a disease, a sphere close to every person, regardless of their political beliefs and social status. Thus, the US media appealed to all segments of society, leaving no one indifferent.

With the temperature of the cold war rising swiftly to fever heat we can no longer ignore the possibility of explosion by May $27^{\text {th }}$ (1959).

Although the second phase of the cold war was characterized by the maximum escalation of the confrontation, there was an awareness that the character of the existing relationship was wrong, which was metaphorically reinterpreted through physical and psychological health and expressed in the LSFs "Psychology", "Physical illness" and "Mental illness".

Cold war and psychological warfare are unfortunate terms (1953).

A top level conference could be used adroitly by Russia to soothe the internal pains and at the same time widen the Western splits (1953)

Tensions of the cold war are not having a salutary effect upon the mental health of America (1958).

\subsubsection{COLD WAR as the target domain of metaphorical transfer}

Political metaphor. During the second stage of the research, internal political battles in governmental departments and committees began to be compared with the cold war.

President Eisenhower's prediction before last year's Congressional election, that, if the Democratic party were given control of Congress a "cold war of partisan politics could ensue" has been borne out by the record (1955).

With the cold war acquiring a regional character, the COLD WAR concept became a target of metaphorical expansion in the situation of regional actors' confrontation, leaving aside the confrontation of the superpowers. The confrontation was of a local character, as opposed to the original global confrontation.

A leading Indian newspaper chain said today that Communist China has declared a cold war against India which is forcing this country to forget about nonalignment. (1959).

Metaphor of education. The seme of a non-military confrontation, which is focal for the COLD WAR concept, started to be transferred to the sphere of education that is far enough away from the original spheres of the conflict.

Chairman Lewis L. Strauss of the Atomic Energy Commission warned Monday that the United States is in danger of losing "the cold war of the classrooms" in which scientific talent is trained (1955). 


\subsubsection{COLD WAR demetaphorization}

It is essential to note the demetaphorization of the COLD WAR concept, which first began to occur within the first decade of the conflict. The lexemes comprising the name of the concept were used in their literal meanings in order to achieve a greater impact on recipients. For example, winter military exercises were reinterpreted through the prism of the cold war.

IT'S TRULY COLD WAR - Gunner Aubrey Johnson, right, and his battery mate take a snow bath near Fort Churchill, Manitoba, Canada, during winter maneuvers on the Arctic tundra. Completion of the snow house, in background, is one of their assigned exercises (1956).

All these metaphorical models are built into the structure of the COLD WAR concept in the period from 1953 to 1962 . The Temperature slot in the second stage turned into a subframe and included the Climate slot. The Spheres subframe structure retained the Game, Politics, and Education slots, as well as the Methods subframe's Warfare slot. The Health subframe emerged as a new component of the concept (see Diag. 4). The example of the demetaphorization of the concept structurally corresponds to the Warfare component that evolved into a subframe.

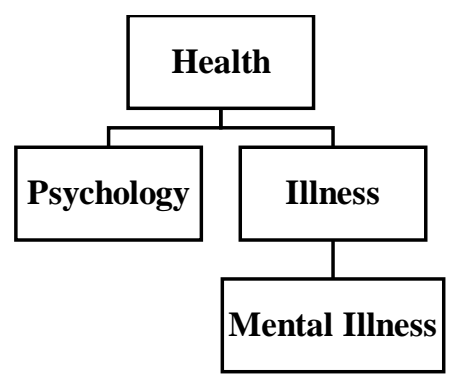

Diagram 4

\subsection{The COLD WAR concept's figurative component (1962-1969)}

\subsubsection{COLD WAR as the source domain of metaphorical transfer}

Temperature metaphor and climate metaphor. Examples of temperature and climate metaphors are the most frequent, since the "cold" lexeme in the phrase "cold war" provides fertile ground for its metaphorical reinterpretation. The same can be said about the "thaw" in relations between the two superpowers.

The United States and the Soviet Union are quietly negotiating a consular treaty which could chip more frost from the Cold War and ultimately, aid in any increased US.Soviet trade (1963).

This means that the Republicans as a party are going to be in a position to claim some credit for the sunshine if this venture should in truth help to melt the cold war ice cap (1967).

Secretary of State Dean Rusk called on the Soviet Union today to withdraw its troops from Czechoslovakia as promised and said the world which had begun to speak of a thaw in the Cold War feels once again a chill of apprehension concerning Soviet purposes (1968).

Military metaphor continued to play a significant role in the reinterpretation of the concept under study, with the cold war being considered as a weapon, which undoubtedly highlights the danger and gravity of the situation on the international stage.

Roscoe Drummond says African nations are determined to keep out of the cross-fire of the Cold War (1965). 
Game metaphor. Comparison with games is typical of all types of confrontation, and the cold war in all its manifestations was no exception. In the second phase of the world conflict the number of game metaphors rose.

Soviet Premier Khrushchev's biggest cold war gamble is not Berlin or Viet Nam or any other of the world's hot spots. It is in Soviet agriculture (1962).

A high-ranking officer in the Soviet secret police was in seclusion under U.S. protection today while American officials assessed his defection as a top prize in the cold war espionage game and the key to at least two spy rings in West Germany (1967).

Religious metaphor. The confrontation between the US and the USSR was described in religious terms, with the religiosity of US citizens being presented as an undeniable advantage in the conduct of the conflict. It was closely connected with the value system and the worldview of "free" democratic nations as opposed to the "enslaved" communist world.

VICTORY - Yet even today, the West's chances of victory are immense. The Communists must meet the crisis of "freeing" all its slaves from God in order to succeed.

We must survive the crisis of indifference towards God simply to exist. As a former Communist once stated, our chances of victory are good, “... but only provided that its (the Free World's) faith in God and the freedom He enjoins is as great as Communism' faith in Man (and his ability to stand alone)." The choice then is clear: brotherhood and unity in God - or eventual Communist enslavement (1967).

Zoomorphic metaphor. The cold war was compared to a venomous snake, which indicates the awareness of the danger of conflict by the American public and the likelihood that it can easily get out of control. The negative connotation of the conflict was being ingrained in the US political discourse.

After nearly twenty-five years of venomous Cold War, Soviet-American détente is still a fragile vessel which it behooves both sides not to try to overload, lest it founder when barely launched (1973).

\subsubsection{COLD WAR as the target domain of metaphorical transfer}

Political metaphor. Like in the first two stages of the cold war, political metaphor was highly illustrative in the context of the COLD WAR concept in American political discourse. The internal policy of the country was reinterpreted through the prism of the world conflict.

A sidelight of the tax-cut affair is the "cold war" between presidential economic adviser W.W. Heller and Treasury Secretary Douglas Dillon (1963).

Has Cold War Ended Between Foreign Relations Committee And the State Department (1969)?

Metaphor of interpersonal relationships. During the development of the concept, the confrontation began to be transferred to the informal spheres of human life, in particular to the sphere of interpersonal relations and the family, and the conflict of generations, in particular. It proves the fact that the COLD WAR concept went beyond political discourse and started to be associated with day-to-day activities.

Cold War Between the Generations (1963).

A hair-pulling cold war is on between Pat Nugent - Luci Johnson's fiancé - and her hairdresser, Jean Louis (1966).

\subsubsection{COLD WAR demetaphorization}

At the third stage of the existence of the COLD WAR concept its demetaphorization continued, and its cases became more frequent in comparison with the previous stages. For example, a cold was compared to the cold war, since both these phenomena are extremely difficult to get rid of. 
Some fouls have colds, one after another, all winter long, and sometimes in the spring and fall, and once in a while, even in the summer. Others go for years without a cold. So far as I know, the cold question is as unsolved as the cold war (1967).

Frozen products that appeared in stores competed with traditional ones, and this rivalry gave rise to a comparison with the global confrontation, and this war was "cold" in the literal sense.

A cold war is going on in the nation's 227.000 food stores as frozen food products are slowly but steadily putting the chill on more and more food items. According to a survey, some 200 new varieties of frozen food items are introduced each year. Currently, about 1,500 different kinds of frozen food are available, although the average supermarket carries only 400 (1969).

There also appeared shoes advertisement that suggested fighting the cold, thereby appealing to the subconscious of potential buyers who were in fear of the cold war. As is known, fear is one of the most efficient ways of manipulating public consciousness.

Fight the cold war. When winter goes on the attack with freezing temperatures and chilling winds ... (1969).

The metaphorical models of the third stage are reflected in the structure of the COLD WAR concept in the following way: the Climate slot of the Temperature subframe became a subframe, and included the Thaw slot (see Diag. 5), the Warfare, Danger, and Health subframes, as well as the Game, Religion, and Politics slots, remained unchanged in the concept structure, while the Spheres subframe was significantly enriched with Interpersonal Relationships, Food, and Advertising slots (see Diag. 6).

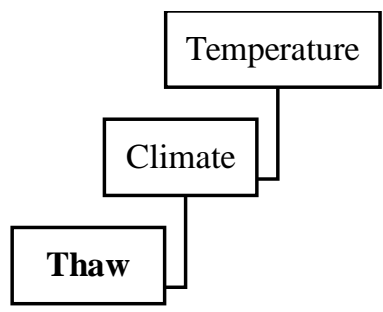

Diagram 5

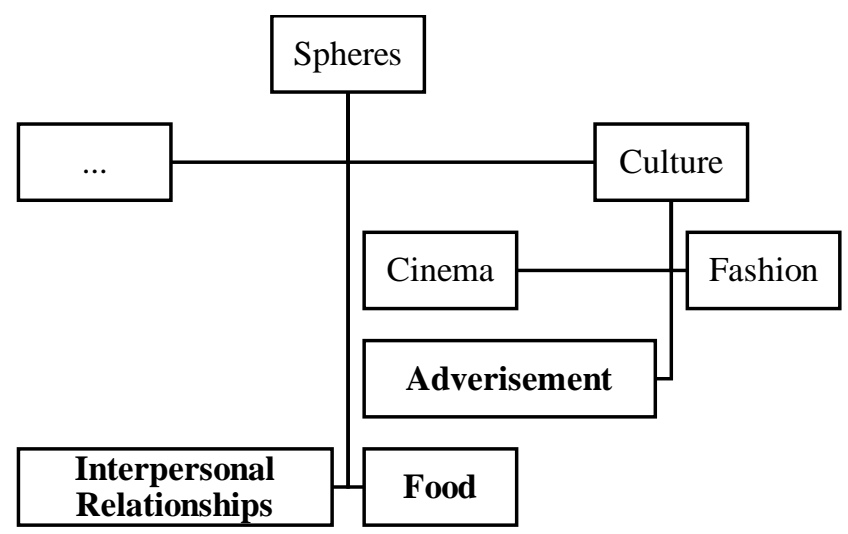

Diagram 6 


\subsection{The COLD WAR concept's figurative component (1969-1979)}

\subsubsection{COLD WAR as the source domain of metaphorical transfer}

As the source domain, the COLD WAR concept at the fourth stage of the cold war was illustrated with its traditional temperature, climate, and game metaphor. Temperature metaphor continues to reflect the variety of vocabulary describing the state of relations between opposing blocs. Climate metaphor interprets the political climate in the international arena, emphasizing the necessity to put an end to the confrontation.

The cold war isn't over, but very significant moves are being made in that direction. The climate must first be created before the cold war can be terminated. The Soviet summits are creating that climate (1973).

For over twenty years our political climate has been dominated by one issue communism, a fear of Russia and of China, of "fellow travelers" and "pinkos". The "cold war" had been won, but we may have blown our victory in Vietnam (1975).

Game metaphor, as in the previous stages, is based on the semes of confrontation and competition, and is represented through chess terms.

Aided and abetted by the old, cold war warriors out of the cold war past, the checkmate of the bold Brandt initiative seems likely to succeed (1971).

\subsubsection{COLD WAR as the target domain of metaphorical transfer}

The COLD WAR concept in the fourth stage of the cold war became the target of gastronomic metaphorization, i.e., metaphorically, the implementation of the detente policy was represented as the preparation of complex gourmet dishes. This highlighted the complexity of the situation and the caution and focus that must be put for the successful implementation of this policy.

Between them, the Americans and Russians have whipped up an enticing batch of icing for their detente cake. But painfully visible and rock-hard lumps remain beneath, stirred in over generations of cold war (1973).

These metaphorical models of the COLD WAR concept at the fourth stage accentuate the already described cognitive features. In the structure of the concept-scenario, they are represented by the Temperature subframe, and the Game and Food slots of the Spheres subframe.

\subsection{The COLD WAR concept's figurative component (1979-1991)}

\subsubsection{COLD WAR as the source domain of metaphorical transfer}

At the final stage of the cold war, the concept of COLD WAR continued to act as a source-domain of metaphorical transfer. It can be exemplified with temperature, climate, and game metaphors already presented at the previous stages of the concept's existence.

Basically, the MX plan is to play nuclear hide-and-seek with the Soviets. America's contribution to the fun will be a giant game board spread over miles of Utah and Nevada where the MXs will be sited (1981).

... huge flows of money and technology to the East will occur only if West Europeans are confident that what they provide won't be destroyed by hot war or, in effect, frozen by renewed cold war (1987).

\subsubsection{COLD WAR as the target domain of metaphorical transfer}

At the final stage, the concept of COLD WAR was subjected to anthropomorphic metaphorization, i.e. the cold war was presented as a living organism that goes through the entire life cycle from birth to death (and rebirth into something new). Interestingly, despite the fact that the cold war was not over yet, politicians were already afraid of its revival. Also, the 
cold war was described in terms of death, with the "death" (ending) of the cold war being perceived exclusively in a positive way.

The president said the Cuban controversy must be kept in perspective. He maintained it is no reason for a rebirth of the cold war (1979).

The old-timers who gather weekly to square dance at the Hamburg Senior Citizen Center do their best to ignore the nearby radar towers, which remind them they're dancing on the grave of a Cold War missile silo (1983).

Wells' lectures now reflect his belief that the Cold War is "dying a slow death. I'm sure people still believe the Soviet Union is antagonistic, but the events of the last three years don't show that," he said (1989).

Political metaphor that emphasizes the seme of nonviolent confrontation was also present at the last stage of the cold war. The accentualization of the same seme can be seen in the spheres of business, sports, and through the use of morbial metaphor.

To be charged with wanting to bring back the Cold War is something of the order of being charged with wanting to bring back cancer (1979).

Palmer, who makes a base salary of \$230,000 a year, has been in a cold war with Orioles' management over salary for several years (1980)

Russian Olympians getting Carter's message. Jimmy Carter won't be on hand for Wednesday's Opening Ceremonies of the Winter Olympics, and that's too bad, because if he were, he'd find out first-hand how surprisingly well he's doing in his personal cold war with the Russians over the Summer Games. It took him a while, but he's finally “winning”(1980).

Republican candidate for governor Andrew O'Rourke says Gov. Mario Cuomo should accept responsibility for problems in the schools, but has conducted a "cold war" against the Board of Regents instead (1986).

Within the framework of the metaphor of interpersonal relationships and family, problems arising in marriage (e.g. this "Cold War" of married life (1987)) were compared to the confrontation during the cold war, characterized by maximum tension, but devoid of open conflict.

\subsubsection{COLD WAR demetaphorization}

At the last stage of the cold war, there were also cases of metaphorization of the COLD WAR concept. We are talking again about using the cold lexeme, as well as its synonyms, in its original meaning in relation to air temperature. This stylistic technique makes speech more imaginative and convincing.

Real cold war waiting for Spartak ice tickets. The rush for a chance to see the Russians didn't get that hot at high noon Wednesday on the Plattsburgh State campus. In fact, it was somewhat of a cold war. Only 25 people braved icy conditions outside the Plattsburgh State Field House ... (1986).

THE CHILLY WAR - The Cold War is getting downright frigid - literally ... Public buildings were practically without heat ... Even the Soviet Embassy had reportedly sent its dependents home because of the lack of heat and hot water (1985).

These metaphorical models were reflected in the structure of the COLD WAR concept at the final stage of the cold war. The new components in the concept model are the Olympics slot as part of the Sport component that became a subframe and the Business slot (see Diag. 7). Other metaphorization models and demetaphorization cases prove the presence of the components already described in the COLD WAR concept. 


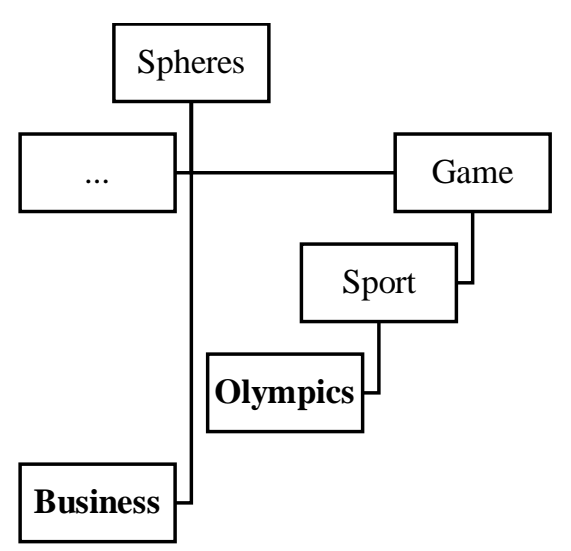

Diagram 7

\section{CONCLUSIONS}

It follows that the dynamics of the figurative component, although to a lesser extent than the dynamics of the nominative component, is determined by extralinguistic reality, but differs in the nature of its changes.

Firstly, the most obvious temperature metaphor characteristic of the COLD WAR concept remained relevant throughout the cold war and thus reflected the relationship between the warring blocs.

Secondly, the seme of nonviolent confrontation of the COLD WAR concept, which appeared as a result of the concept acting as a source of metaphorical transfer, led to the use of the concept in the spheres of human activity, unrelated to the original confrontation of the two superpowers - in the field of sports, business and personal relations.

Thirdly, the development of the concept is also indicated by the anthropomorphic nature of its metaphorization, the growing number of metaphors that somehow "humanize" the concept of COLD WAR. It also needs to be noted that cases of demetaphorization gradually increased in number, that is, the lexemes that make up the "cold war" phrase were used in their literal meanings in order to achieve a greater impact on the audience.

\section{REFERENCES}

1. Babushkin, A.P. (1996). Tipy konceptov v leksiko-frazeologicheskoj semantike jazyka [Concept types in the lexical and phraseological semantics of a language]. Voronezh: VSU (in Russian).

2. Chudinov, A.P. (2011). Sovremennaja politicheskaja lingvistika: uchebnoe posobie [Modern political linguistics: a textbook]. Ekateriburg: USPU (in Russian).

3. Cowley, R. (Ed.). (2006). The Cold War: a military history. Random House.

4. Crockatt, R. (1994). The fifty years war: the United States and the Soviet Union in world politics, 1941-1991. London; New York: Routledge Taylor \& Francis Group.

5. Dem'jankov, V.Z. (1994). Kognitivnaja lingvistika kak raznovidnost' interpretirujushhego podhoda [Cognitive linguistics as a type of interpretive approach]. Voprosy jazykoznanija [Issues of linguistics], 4, 17-33 (in Russian).

6. Dijk, T.A. van. (Ed.). (1997). Discourse as structure and process. Discourse studies: A multidisciplinary introduction. Volume 1. London; Thousand Oaks; New Delhi: Sage Publication.

7. Dockrill, M.L., \& Hopkins, M.F. (2006). The Cold War, 1945-1991. $2^{\text {nd }}$ edition. Palgrave Macmillan. 
8. Egorova, N.I. (2003). Holodnaja vojna. 1945-1963 gg. Istoricheskaja retrospektiva. [Cold War. 1945-1963. Historical retrospective]. Moscow: OLMA-PRESS (in Russian).

9. Gaddis, J.L. (1998). We now know: rethinking Cold War history. Oxford: Clarendon Press.

10. Halliday, M.A.K. (1978). Language as social semiotic: the social interpretation of language and meaning. London: Arnold.

11. Karasik, V.I. (2002). Jazykovoj krug: lichnost', koncepty, diskurs [Language circle: personality, concepts, discourse]. Volgograd: Peremena (in Russian).

12. Kendall, B. (2017). The Cold War: a new oral history of life between East and West. BBC Books.

13. Kovalev, N.A. (2017). Razvitie koncepta "HOLODNAJA VOJNA" v politicheskom diskurse (na materiale amerikanskih SMI) [Development of the "COLD WAR" concept in political discourse (based on the material of the American media)]. Filologicheskie nauki. Voprosy teorii i praktiki [Philological science. Issues of theory and practice], 7 (73), part 1, 98-102 (in Russian).

14. Kubrjakova, E.S., Dem'jankov, V.Z., Pankrac, Ju.G., \& Luzina, L.G. (1996). Kratkij slovar' kognitivnyh terminov [Concise dictionary of cognitive terms]. Moscow: MSU (in Russian).

15. Lakoff, G., \& Johnson, M. (2003). Metaphors we live by. London: University of Chicago Press.

16. Leffler, M.P., \& Westad, O.A. (2010). The Cambridge history of the Cold War: Volume 1, Origins. Cambridge University Press.

17. Minsky, M. (1975). A framework for representing knowledge. In P. Winston (Eds.) The psychology of computer vision, New York: McGraw-Hill, 211-77.

18. Orwell, G. (1945). You and the atomic bomb. Tribune; London.

19. Shejgal, E.I. (2000). Semiotika politicheskogo diskursa [Semiotics of political discourse]. Volgograd: Peremena (in Russian).

20. Tolstaja, S.M. (2004). "Chelovek zhivet, kak trava rastet": vegetativnaja metafora chelovecheskoj zhizni ["A person lives like grass grows": vegetative metaphor of human life]. Sokrovennye smysly. Slovo. Tekst. Kul'tura [Hidden senses. Word. Text. Culture], Moscow, 685-693 (in Russian). 